\title{
Nilainisasi Pembelajaran Sains (Upaya Pembelajaran Integrasi-Interkoneksi Agama Dan Sains)
}

\author{
Amril \\ Universitas Islam Negeri Sultan Syarif Kasim Riau, Indonesia \\ e-mail: amrilm@uin-suska.ac.id
}

\begin{abstract}
.
This study aims to explore science learning models that are integrated and interconnected with religious values. This research is library research. The data source used is literature related to the concepts of science learning and the concept of philosophical values. For this reason, the data analysis used is the content of the analysis with a qualitative approach. The data obtained through reading various sources are selected first, then categorized and then analyzed. The results of this study are the need for science learning based on three things, namely: hadharat an-nash (text culture), hadharat al-'ilm (culture of science) and hadharat al-falasafah (philosophical-ethical culture) then followed by implementing a philosophical approach - scientific analysis and explanative approach and exploration of religious and social values in practical learning, can be said to be a learning structure of science that no longer leaves values. In such a negative derivative produced by science learning that leaves values undoubtedly can be eliminated, on the contrary science will certainly emerge that is in favor of divinity, humanity and ecology, then the scientific product which will emerge li al-'alamin will open up.
\end{abstract}

Keywords : Learning Science, Integration, Interconnection, Religion, Science

\begin{abstract}
ABSTRAK.
Penelitian ini bertujuan untuk mengeksplor model pembelajaran sains yang terintegrasi dan terinterkoneksi dengan nilai-nilai agama. Penelitian ini merupakan penelitian kepustakaan (library research). Sumber data yang digunakan adalah literatur yang terkait dengan konsepkonsep pembelajaran sains dan konsep nilai (values) dalam filosofis. Untuk itu analisis data yang dipakai adalah content analisys dengan pendekatan kualitatif. Data-data yang diperoleh melalui bacaan berbagai sumber diseleksi terlebih dahulu, kemudian dikategorisasi dan dianalisis selanjutnya diambil kesimpulan. Hasil penelitian ini adalah perlunya pembelajaran sains didasarkan pada tiga hal, yaitu: hadharat an-nash (budaya teks), hadharat al-ílm (budaya ilmu pengetahuan) dan hadharat al-falasafah (budaya filosofis-etis) kemudian diikuti dengan mengimplementasikan pendekatan filosofis-analitik saintifik dan penedekatan eksplanatif dan ekploratif nilai keagamaan dan sosial dalam praktis pembelajaran, dapat dikatakan merupakan sebuah struktur pembelajaran sains yang tidak lagi meninggalkan values. Sedemikian rupa turunan negatif yang dihasilkan oleh pembelajaran sains yang meninggalkan values niscaya dapat dieliminasi, sebaliknya tentu akan lahir sains yang berpihak pada keilahiyahan, kemanusiaan dan ekologial, selanjutnya akan terbuka produk sains yang rahmatan li al-'alamin.
\end{abstract}

Kata kunci: Pembelajaran Sains, Integrasi, interkoneksi, Agama, Sains

\section{PENDAHULUAN}

Stigma negatif terhadap kinerja pembelajaran sains saat ini sudah menjadi pengetahuan masyarakat khususnya para praktisi pendidikan yang peduli akan capaian pendidikan yang sesungguhnya. Banyak memang penyebab yang melahirkan ketidak puasan 
terhadap kinerja pembelajaran sains yang mengenyampingkan values bahkan sama sekali menafikannya.

Keberlangsungan pembelajaran sains seperti ini telah banyak dikritik oleh para pemerhati pendidikan terutama pada kekurang keberpihakan pada values yang merupakan bagian substantif dari pendidikan itu sendiri. Muhmidayeli (2005: ix) secara tegas mengatakan bahwa sekalipun sekolah pada posisi centre of excellence dalam membangun peradaban masyarakat, ....ternyata harapan itu belum memuaskan boleh jadi lebih dikarenakan sekolah kurang lagi mampu menjalankan fungsionalitas internalisasi nilai-nilai (values) kepada anak didiknya.

Ketidak mampuan fungsionalitas menginternalisasikan values kepada siswanya ini diantaranya dikarekan struktur pembelajaran sains yang memang tidak mendukung terinternalisasikannnya values khususnya dalam pembelajaran sains. Amril M misalnya mengungkapkan paling tidak ditemukan secara umum empat kondisi dalam struktur pembelajaran sains ini yang dinilai penyebab kinerja pembelajaran ini kurang berpihak pada values, yakni 1. Aksentuasi pembelajaran pada teori dan mengejar product, 2. Dikhotomi sains dan ilmu-ilmu sosial dan kemanusiaan serta tuntutan spesialisisasi capaian sains yang dipatok sangat kaku dan berwatak diametrical. 3. Kebijakan pendidikan dan budaya sekolah yang diskriminatif antara kelompok bidang mata pelajaran dan 4. Tuntutan ideologibirokrasi yang sentralistik yang menuntut adanya keistimewaan mata pelajaran tertentu ( Amril M, 2013:68)

Struktur pembelajaran sains yang umumnya berlangsung seperti dipaparkan di atas menurut Jean-Pierre Wills bahwa setidaknya ada tiga ranah yang mesti terikutkan dalam proses pembelajaran jika dikaji dari makna semantik pendidikan itu sendiri yakni 1. pemahaman yang mendalam terhadap sesuatu pengetahuan. 2. nilai moral dan 3. sikap. (Wils, 1987: 107). Ketiga ranah ini mesti dilakukan dalam suasana pembelajaran yang dinamis dan rekonstruktif dalam lingkup menjawab pertanyaan apa, kenapa dan bagaimana secara bergejalinkelindan tanpa sikap dominasi dan diskriminasi satu untuk kepentingan yang lain. (Amril M, 2013: 67)

Kinerja pembelajaran sains dilontarkan pula oleh Ian G. Babbour (Babour, 1966: 151) bahwa, guru-guru sains memberi perhatian lebih pada the logic of the discovered dibanding the process of discovery. Implikasi dari pendapat ini dapat dikatakan bahwa model pembelajaran lebih pada tahapan-tahapan sebagai rules of action yang mesti dilalui untuk mencapai hasil pembelajaran sains, sebaliknya model pembelajaran kurang teraksentuasi misalnya pada persoalan-persoalan ontologis dan aksiologis apa yang terikutkan dalam mempelajari sebuah materi sains sehingga persoalan metascience dan metaethics akan mengisi kekurangan model pembelajaran sains yang banyak dikritik saat ini.

Menelaah struktur kinerja pembelajaran sains di sekolah bahkan di perguruan tinggi yang berlangsung saat ini sulit untuk mengatakan bahwa kinerja pembelajaran sains berlangsung pada tiga ranah proses penembelajaran yang secara niscaya akan mengikutkan values dalam pembelajaran secara terstuktur dan terencana. Alhasil apa yang didapatkan dari hasil capaian pembelajaran sains saat ini terhenti pada ranah knowledgean sich sementara pada dua ranah lainnya; nilai moral dan sikap sebagai ranah values kurang mendapat sentuhan malah cenderung diabaikan. 
Upaya membenahi kinerja pembelajaran sains saat ini secara struktur memang telah diciptakan, setidaknya tercermin pada Kurikulum 2013. Kurikulum ini lahir tidak saja ditujukan guna menjawab kelemahan capaian pembelajaran saat ini di tengah persaingan global yag tidak dapat dihindari, sesungguhnya juga menjawab keprihatinan pembelajaran sains yang ditenggarai telah meningalkan values dalam pembelajarannya. Hanya saja terapan praktis yang berjalinkelindan keempat KI 1, KI 2. KI 3 dan KI 4 yang dituntut K13 ini masih banyak menghadapi kendala bahkan menemui kebuntuan untuk dilksanakan

Integrasi-interkoneksi itu sendiri dalam konteks tulisan ini sesungguhnya dipahami dalam bentuk hubungan keterpaduan atau saling mengisi dan melengkapi antara elemenelemen sains dan values dalam sebuah kinerja pembelajaran guna memberikan pemahaman yang koprehensif di balik fakta dan data sains.(Amril M, 2016:33) Values merupakan diantara entitas yang tidak bisa ditinggalkan begitu saja di dalam fakta dan data sains itu sebagaimana akan diuraikan dalam tulisan ini.

Model pembelajaran integrasi-interkoneksi agama dan sains sesungguhnya dapat dijadikan tumpuan harapan untuk memberikan jawaban solusif atas stigma negatif terhadap pembelajaran sains yang berlangsung selama ini seperti dipaparkan di atas.

Tawaran seperti ini sejatinya bukan tanpa alasan, sesungguhnya banyak alasan yang dapat diberikan misalnya bukankah diantara misi integrasi ilmu dan agama itu adalah nilainisasi.(Amril M,2008,199-227). Di sini values keberadaannya sungguh tidak terpisahkan sama sekali dengan sains, karena setidaknya dalam perspektif filosofis dan kultural, sains dan values itu hidup dalam suatu tempat yang sama yaitu masyarakat. (Amril M, 2013: 16)

Tulisan ini tidak dimaksudkan untuk menambah panjang hujatan negatif terhadap pembelajaran sains yang menelantarkan values, tetapi mencoba menawarkan alternatifsolusif demi penguatan struktur pembelajaran sains sehingga prilaku pembelajaran sains berpihak kepada values sebagai bagian yang niscaya ada pada sains itu sendiri. Khususnya lagi di lembaga-lembaga pendidikan Islam termasuk PTKIN/S yang membawa misi capaian akhir pendidikannya pada abklaq al-karimah yang secara dasariah dibangun di atas values.

\section{HASIL DAN PEMBAHASAN}

\section{Sains dan Nilai Moral Dalam Pendidikan}

Secara semantik sains itu bermakna kumpulan teori hasil dari ujicoba, kemudian menjelaskan tentang pola-pola yang teratur ataupun yang tidak teratur diantara fenomena yang dipelajari (Harre, 1995: 62). Pemahaman sains seperti ini juga diperkuat oleh Capleston yang mengatakan bahwa tekan usaha pada sains itu pada aktivitas telaah relations between things than the inner nature of things (Capleston Vol. V,1975: 275).

Pertanyaan yang mendasar pada saat ini diantaranya mungkinkah kinerja sains, baik dalam pembelajaran ataupun penelitian, sebagaimana yang telah dipatok dalam makna semantik sains itu seperti pendapat ahli di atas, dilanjutkan pada apa yang disebut dengan meta science dan values sehingga kegagalan pembelajaran sains yang tidak mengiternalisasikan eksistensi values dapat diakhiri.

Terasa sulit memang untuk mengabulkan permintaan seperti pertanyaan di atas, karena "pen-tasybih-an" atau "pen-sacral-an" terhadap sains sebagai bidang ilmu pengetahuan yang tidak tersentuh oleh values selain secara historis telah cukup berlangsung 
lama, tetapi lebih dari itu yaitu model pemikiran positivisme sebagai basis epistemologis sains, telah pula di-tasybih-kan sebagai instrumen utama keberhasilan sains sampai kepuncak dan kedigjayaannya saat ini tak terbantahkan.

Kedigjayaan sains dan teknologi memang tak terbantahkan terutama keberhasilannya yang telah memudahkan perilaku kehidupan di alam jagad raya ini, bahkan kedigjayaan ini justru telah pula mengubur kemanusiaan dan keilahiyahan dalam kehidupan alam jagad raya ini. Sedemikian rupa sains dan teknologi telah menggantikan kemanusiaan manusia dan Tuhan yang sesungguhnya sebagai sabjek dalam kehidupan ini.

Pada sisi terakhir keberhasilan sains dan teknologi ini lah sesungguhnya yang mesti yang mesti dijadikan lahan perbaikan oleh kinerja pendidikan termasuk pembelajaran sains di lembaga-lembaga pendidikan dan penelitian serta pengembangan sains kemasa-masa selanjutnya. Bagaimanapun juga perilaku negatif sains yang dihadapi peradaban umat manusia saat ini sesungguhnya tidak dapat dipisahkan sama sekali dari kinerja pembelajaran dan pengembangan sains di lembaga-lembaga pendidikan dan penelitian. Karenanya pembenahan kinerja pembelajaran dan pengembangan sains yang menempatkan values sebagai bagian yang tidak terpisahkan dari sains itu sendiri perlu segera diimplementasikan.

Pendidikan termasuk lembaga pendidikan dan penelitian memiliki peran strategis untuk menghadapi tuntutan seperti ini, bukanlah sesuatu yang berlebihan, untuk mengatakan bahwa fungsi pendidikan termasuk lembaga pendidikan dan penelitian, memiliki peranan ganda yang satu sama lain tidak dapat dianak emaskan dan yang lain dianak tirikan apa lagi dipisahkan. Menurut Prof. Dr. Muhmidayeli, M.Ag (2011:39) bahwa pendidikan itu sesungguhnya mengusahakan dua kepentingan pendidikan yanitu; pertama wilayah humanistic: pengembangan akademik ilmu-ilmu murni dan nilai-nilai dan kedua wilayah man power. pengembangan keterampilan, dan pengetahuan praktis yang besifat teknologis dan ilmu terapan. Kedua wilayah ini saling terkait satu dengan lainnya dan saling menyempurnakan bagi tercapainya missi substantif pendidikan. Tegasnya bahwa ranah sains dan values merupakan bagian yang inheren dalam pendidikan, memisahkan values dari sains apa lagi mengorban dan menafikan values sebagai refresentasi wilayah bumanistic demi mengejar kepentingan sains sebagai represntasi wilayah man power, niscaya ditenggarai hanya akan melahirkan sains-sains yang buta sehingga dengan mudahnya melabrak kemuliaan kemanusiaan dan kepentingan ekologis, bahkan teologis.

Dalam konteks pemaknaan seperti ini lah dikatakan bahwa struktur pembelajaran sains yang berbasiskan values menjadi jalan solusif bagi pembenahan pembelajaran sains saat ini yang telah menjadi kegelisahan para ahli seperti diungkap dimuka.

Sebelum menelaah lebih lanjut tentang bagaimana semesti pembelajaran sains yang dapat bersentuhan dengan values sebagai jawaban solusif atas keprihatinan pembelajaran sains saat ini yang telah banyak dikritik oleh berbagai ilmuwan, maka terlebih dahulu akan diekplorasi bagaimana relasi sains dengan masyarakat dan kemudian hubungan keduanya ini dengan pendidikan. Melalui telaah seperti ini dimungkinkan betapa pembelajaran sains mesti diberlakukan tidak terlepas sama sekali dengan values.

Setidaknya tiga entitas yakni sains, masyarakat dan pendidikan mesti ditempatkan dalam bentuk hubungan bangunan segitiga sama sisi yang masing-masing titik ujungnya saling menyentuh. Misalkan titik A adalah sains, titik B adalah masyarakat dan titik C adalah pendidikan. Bangunan segitiga sama sisi tak akan terbentuk ketika ketiga sisinya bersentuhan. Melalui bangunan segitiga sama sisi seperti ini menggambarkan bahwa antara sains, masyarakat dan pendidikan tidak dapat dipisahkan satu dengan lainnya. Misalnya titik A tidak dapat dipisahkan dengan titik B. Dan titik C tidak dapat dipisahkan dengan titik A 
dan B begitu seterusnya. Salah satu saja titik itu terpisah dari yang lainnya maka bangunan segitiga sama kaki tersebut juga akan rusak.

Gambaran bangunan segitiga sama kaki tersebut diatas dapat diuraikan betapa sains, masyarakat dan pendidikan merupakan tiga entitas yang tidak dapat dipisah-pisahkan. Penjelasan relasi sains, masyarakat dan pendidikan sebagai berikut

Secara akademis dan sosiologis keinginan pembelajaran sains yang berpihak kepada masyarakat setidaknya dikarenakan telah terjadi pemaknaan substantif dari sains itu sendiri. Saat ini pemahaman sains tidak lagi sebatas knowledge sebagaimana padan kata dari scientia (latin) yang melahirkan pemaknaan sains seperti disebutkan diatas sebagaimana yang ditampilkan R. Harre (1995: 62), tetapi buah dari kajian yang mendalah tentang sains terutama dari kajian epistemologi maka pemaknaan sains saat ini merupakan sebagai ilmu pengetahuan yang tidak lepas dari hasil " rekayasa" olah pikir akal budi manusia yang terikat oleh ruang dan waktu dan kondisi psikis, sosiologis dan ideologis di saat sains itu dilahirkan atau dikembangkan.(Amril M, 2013: 8)

Pergeseran cara pandang para ahli terhadap sains seperti disebutkan di atas, juga ditemukan pada pendapat Henk Verhook (1985: 99) yang mengatakan bahwa temuan dan pengembangan sains itu merupakan hasil social activity. Karenanya, lanjutnya lagi bahwa sains itu tidak dapat dipisahkan dari nilai-nilai sosial budaya dan agama.Dengan terminologi research kita dapat katakan bahwa sesungguhnya sains itu tidak lagi berada pada posisi determinat tetapi sesungguhnya pada posisi indeterminant.Sains merupakan hasil perlakuan oleh banyak entitas di luar dirinya, termasuk nilai-nilai sosial dan individual dari sekelompok atau individu saintis itu sendiri yang tidak terpisahkan dari nilai-nilai sosial dan individual yang melekat dalam kehidupan mereka. Oleh karena itu pendapat yang mengatakan bahwa sains itu free values dan dependent dan seumpamanya perlu dikoreksi dan dipahami secara proporsional.

Uraian singkat di atas mempertegas bahwa secara ontologis bahwa sains itu sebuah entitas yang dilahirkan oleh kungkungan lingkaran waktu dan tempat dimana nilai-nilai keagamaan, kemanusiaan dan sosial, hidup didalamnya, dalam hal ini masyarakat. Sedemikian rupa semua nilai-nilai ini akan selalu menggayuti, bahkan bagian yang tidak dapat dipisahkan dari sains itu sendiri baik dari awal pencarian dan pengembangannya maupun sains sebagai produk yang dimanfaatkan oleh manusia

Menyadari pemaknaan eksistensial seperti di atas menunjukkan secara eksplisit bahwa sains bagian yang tidak terpisahkan dari kehidupan yang sarat dengan nilai-nilai sosial, budaya, agama dan kemanusiaan. Relasi sains dengan pendidikan juga tidak dapat dipisahkan, bahkan saling membutuhkan antara sains dan pendidikan.

Amril M (2005:25-60) misalnya telah merumuskan bahwa setidaknya ada tiga bentuk relasi pendidikan dan nilai moral; pertama, keterkaitan substansialitas a priori. Bentuk keterkaitan berlangsung dimana moralitas dan etka membutuhkan proses pendidikan dalam mengaktualisasikan dirinya, sebaliknya pendidikan membutuhkan moralitas dan etika dalam pengungkapan (self-actualitation) dirinya. Tegasnya dimana ada pendidikan disitu juga ada nilai moral dan etika.Kedua; keterkaitan metotologis epistemic, bentuk keterkaitan ini tampil nyata pada upaya pencarian dan merumuskan capaian idealitas dan fungsionalitas yang terakumulasi pada tujuan pendidikan dan pembelajaran dan peran serta fungsi pendidikan dan sekolah itu sendiri.Berpikir filosofis dan metodis untuk mengkontestasikan tujuantujuan pendidikan dan pembelajaran sesungguhnya bagian yang tidak dapat dipisahkan dengan nilai-nilai moral dan etika.Disini dikatakan bahwa pendidikan membutuhkan nilainilai moral dan etika.Ketiga, keterkaitan pembelajaran intellectual skills; bentuk keterkaitan 
intellectual skills sesungguhnya tertampilkan pada siswa di saat mereka memiliki kemampuan mengembangkan dan mentransformasikan dari berbagai materi berbagai ilmu pengetahuan yang telah mereka miliki baik melalui observasi, memprediksi, mengklarifikasi, mengkomuni-kasikan dan menarik kesimpulan yang selanjutnya diimplementasikan dalam menghadapi problema yang dihadapi siswa. Ketepatan memilih berbagai alternatif pilihan dari berbagai kesimpulan yang niscaya didapat untuk diterapkan guna memberikan solusi atas problema yang dihadapi untuk diselesaikan dengan tepat dan baik serta bajik.Ketepatan pilihan memanfaatkan hasil dari intelectual skills ini disebut dengan wisdom.

Tegasnya keterkaitan nilai moral dan etika dengan pendidikan dalam bentuk intellectual skills sesungguhnya mengupayakan beragaman materi pengetahuan yang didapat oleh siswa berhasil ditransferkan kepada values ketika kesimpulan ilmu pengetahuan yang didapat dirterapkan dalam kehidupan.

Uraian di atas mempertegas bahwa pendidikan atau pembelajaran materi pelajaran apapun sekolah tidak dapat dipisah values, demikian pula pembelajaran sains yang sesunguhnya tidak dapat dipisahkan sama sekali dengan values. Tiga keterkaitan pendidikan dan nilai moral dan etika seperti disebutkan di atas sesungguhnya memperkuat misi pendidikan tidak dapat dipissahkan dengan misi nilai-nilai moral dan etika.Implementasinya tentu pada setiap mata pelajaran yang diberikan di sekolah secara niscaya tidak dapat dipisahkan dengan values.

\section{Pembelajaran Integratif-Interkonektif Agama dan Sains: Sebuah Usaha Nilainisasi}

Beragam peran dan fungsi integrasi-interkoneksi sudah cukup banyak diberikan oleh para ahli sehingga menjadikan kajian keilmuan dalam integrasi-interkoneksi begitu luas dan dijadikan pula sebagai paradigma solusif bagi ketimpangan perjalanan epistemologi keilmuan saat ini. (Amril M, 2016: xxvi)

Transfer of values dalam upaya internalisasi dalam pembelajaran diakui, sebagaimana banyak menjadi bidik kritik para ahli pendidikan, kurang mendapat perhatian,proses pembelajaran dan capaian hasilnya serta merta berhenti pada penguasan transfer of knowledge an sich. Atau dikhotomis ilmu pengetahuan sains dan values telah dipaku mati dalam sturuktur pembelajaran. Sedemikian rupa sains dan values diasingkan dan diisolasi secara terstruktur yang tak ada ruang untuk dipertemukan bahkan values dikubur hidup-hidup dalam pembelajaran sains dantidak tertutup kemumgkinan pada ilmu-ilmu sosial dan humaniora yang sesungguhnya memiliki pintu yang terbuka lebar bagi values. Hanya saja dengan mengaksentuasikan pendidikan hanya pada ranah man power dibanding ranah humanistic seperti yang dikatakan oleh Prof. Dr. Muhmidayeli, M.Ag di atas, menjadikan sekolah sebagai ujung tombak utama kinerja pendidikan diseret kearah transfer of knowledge semata.

Sesungguhnya beragam kecaman pembelajaran di sekolah telah diungkapkan oleh para ahli, termasuk sturuktur pembelajaran sains di sekolah yang tidak menempatkan values sebagai terminal akhir dari sebuah capaian pembelajaran.

Dalam perspektif integrasi Islam dan sains, nilainisasi ilmu tentunya tidak dapat dipisahkan dari dimensi nilai-nilai Ilahiyah, moral dan etika. Allah swt sebagai 'alim dan masnusia sebagai subjek (knower) kemudian alam dengan segala fenomenanya sebagai objek (known) pencarian ilmu pengetahuan dan sains tentu memiliki kaitan yang tak terpisahkan satu dengan lainnya dalam suatu bentuk ketertataan hubungan gerak organis dan interrelasi; masing-masing memberi stimulus dan respon bagi yang lainnya. (Amril M, 2008: 205). 
Sang Khaliq sebagai sumber nilai, manusia dan fenomena alam sebagai makhluk tentu nilai inheren dalam dua entitas ini tidak dapat dipisahkan begitu saja dari nilai dari sang Khaliq. Tegasnya dikatakan bahwa nilai yang ada baik pada manusia maupun pada fenomena alam jagad raya merupakan bagian dari nilai ilahiyah.Manusia sebagai knower dan fenomena alam sebagai known sesungguhnya memiliki values yang berakar dari sang Khalik sebagai sumber values. Oleh karenanya apapun usaha manusia sesunguhnya tidak bisa terlepaskan dari oreientasi darillabiyah.

Tegasnya values Ilahiyah sudah menjadi bagian dalam diri masnusia nilai. Demikian juga usaha dalam pendidikan semisal pembelajaran sains, baik guru dan siswa sebagai knower dan fenomena alam sebagai known justru secara inheren telah menjadi bagian dari nilai-nilai itu sendiri.

Posisi manusia yang menjadi bagian dari valuesllabiyah ini dinyatakan dengan tegas oleh Prof. Dr. Muhmidayeli, M.Ag bahwa mengorientasikan segala bentuk karya, rasa dan karsa manusia kepada moral merupakan suatu kemestian jika manusia ingin menjadikan dirinya sebagai manusia dalam gambaran penciptanya (Muhmidayeli, 2008: 231).

Begitu keterkaitan interrelasi values dan manusia serta fenomena alam jagad raya yang telah menjadi bagian inheren dalam entitas mereka masing-masing, tentu pembelajaran sains semestinya tidak dapat terlepaskan dari values baik keilahiyahan, kemanusiaan dan ekologial. Pertanyaannya yang menarik untuk dijawab adalah bagaimana struktur pembelajaran sains yang tersentuh dengan values ini, sehingga mampu menemukan dan menginternalisasikan values ini dalam aktivitas pembelajaran sains itu sendiri.

Untuk menjawab pertanyaan di atas, setidaknya berbagai pendekatan relasi sains dan agama dalam pengembangan dan kajian ilmu dapat dijadikan acuan guna menformat pembelajaran sains yang tidak terpisahkan dari values, misalnya integrasi-interkoneksi, komplementari dan konfirmasi serta filsafat proses Kesemua pendekatan pengkajian dan pengembangan ilmu yang mengikutkan values pada prinsipnya memiliki oirentasi yang sama yakni mengupayakan pengkajian dan pengembangan, termasuk pembelajaran sains tidak terpisahkan dengan values. (Amril M, 2016: 32-55).

Tanpa bermaksud meminggirkan pendekatan lainnya, maka tulisan ini akan memakai pendekatan integrasi-interkoneksi, selanjutnya dikembangkan dalam kerangka struktur pembelajaran sains secara metodis, sedemikian rupa pembelajaran sains yang selama ini meninggalkan values segera dapat dieliminasi .

Misi pendekatan pengkajian dan pengembangan integrasi-interkoneksi ini sesungguhnya merupakan upaya memutus sekat dikhotomis sains dan agama, atau Islam dan ilmu pengetahuan sebagai misi awal pendekatan ini, sehingga temuan sains yang berasal dari luar Islam tidak leluasa begitu saja meningalkan values, terutama values Islami.

Ilmuwan awal abad 21 yang mencuatkan pendekatan integrasi Islam dan ilmu pengetahuan semisal Al-Faruqi, Al-Attas dan Sardar sepakat bahwa pendidikan Islam merupakan pendidikan yang terintegrited, tidak lagi mengenal batas dikhotomis seperti antara ilmu pengetahuan danvalues, (Amril M, 2002:46).

Kuatnya keeinginan menempatkan values kembali dalam pendidikan dan pembelajaran bahkan values ditempatkan sebagai bagian dan bahkan dasar bagi pendidikan dan pembelajaran materi pelajaran apapun, termasuk pembelajaran sains sungguh sangat terasa dari ungkapan para pemikir pendidikan dan pembelajaran saat ini, misalnya E. Schumache mengklaim bahwa task of education would be, first and foremost, transmission of ideas of value, of what to do with our lives (Athur K Eliss; 1986: 28). Jack R. Fraenkel (1977:1) 
menyatakan bahwa Teaching is a value-oriented enterprise, Pendapat di atas sesungguhnya mempertegas bahwa values sebagai dasar pada moral sesunguhnya tidak terpisahkan dalam pendidikan, pebelajaran, bahkan usaha dan kegiatan apapun yang diorganisir di sekolah secara sistemik tidak terpisahkan dengan moral values.

Simpulan yang dapat ditarik bahwa values dalam kinerja pendidikan dan pembelajaran termasuk upaya pengembangan ilmu pengetahuan semisal sains memang tidak dapat ditingalkan, bahkan relasi values dan sains itu bagaikan dua sisi mata uang yang saling melengkapi dan menyempurnakan yang dilakukan dalam satu tarikan napas dalam aktivitas pendidikan dan pembelajaran.

Implimentasi pendekatan integratif-interkonektif dalam pembelajaran sains yang tidak tersekat dan meminggirkan values, setidaknya dapat dilakukan dalam bentuk rekayasa metodis pembelajaran sebagai berikut

1. Pendekatan filosofis-Analitik Saintifik

Dimaksudkan dengan pendekatan seperti ini adalah penekanan pada pembelajaran sains yang lebih pada pembentukan praanggapan dasar filosofis metafisik siswa ketika mempelajari sains yang tujuannya melahirkan pemahaman dari penafsiran prinsip-prinsip dan ajaran-ajaran agama yang demikian adanya dan keniscayaan pengembangan dari prinsip-prinsip dan ajaran agama ini

Dari sini diharapkan akan lahir world view Tawhid; menempatkan Allah sebagai pusat poros pusaran segala makluk-Nya, selanjutnya akan tumbuhkembang pula pandangan dunia metafisik Ilabiyah danvalues agama dan sosial kemanusiaan serta ekologial dari fakta dan data sains dalam pembelajarannya. Dengan menerapkan pendekatan seperti ini anak didik diajak untuk memahami hal-hal values dibalik fakta dan data yang sesungguhnya saat ini merupakan bagian yang tidak terpisahkan dari fakta dan data. Sedemikian rupa anakdidik tidak lagi berfikir yang terhenti pada fakta dan data serta pengalaman tetapi juga justru mereka dilatih dan dapat mengambil pemahaman melebihi dari apa yang ada pada fakta dan data.

Dibalik itu semua tentunya values agama, kemanusiaa, dan sosial sertaalam jagad raya. Kesemua ini bagian yang tidak terpisahkan dengan fakta dan data sainstifim sebagai bahan materi pembelajaran. Melalui pendekatan seperti ini pembelajaran sains akan niscaya melahirkan anak didik yang tidak saja menjadikan mereka sebagai pemilik kompetensi pemakai (consumers) sains an sich, tetapi juga sebagai pemilik kompetensi pengembang (produsers) sains yang berbasis values agama, kemanusiaan, ekological dan sosial. Sedemikian rupa sains dan teknologi yang akan dihasilkan niscaya sudah mengikutkan values setidaknya dalam dalam dangan dunia sisiwa telah terbentuk betapa values sesungguhnya bagian yang tidak terpisahkan dalam setiap fakta dan data yang ada pada sains.

2. Penedekatan Eksplanatif dan Ekploratif Nilai Keagamaan dan Sosial

Dimaksudkan dengan pendekatan eksplanatif dan ekploratif nilai-nilai keagamaan dan sosial adalah penekanan pada kemampuan anak untuk mencermati dan memutuskan ada values dalam setiap fakta dan data sains. Pendekatan seperti ini nanti akan menjelaskan dan menggali tentang keterkaitan fakta dan data sais itu tidak terpisahkan dengan values keagamaan, keberadaan kehidupan, sosial. Model pembelajaran dengan pendekatan seperti ini dapat dilakukan dalam bentuk, misalnya, "pembelajaran dari mengajarkan pengetahuan dan skills saintifik" ke "mengajarkan pengetahuan dan skills saintifik dalam kehidupan individual dan sosial". 
Pendekatan pembelajaran seperti ini juga membutuhkan kemampuan apa yang disebut dengan moral judgments: factual judgments dan values judgments. Factual judgments itu sendiri adalah penilaian-penilaian yang didasarkan pada hal-hal yang dapat diobservasi atau segala sesuatu yang tengah berlangsung yang terikat oleh waktu, tempat dan individu yang melakukannya. Value judgments itu sendiri adalah penilaian-penilaian berdasarkan pertimbangan baik atau tidak baik, mudharat dan manfaat dari aspek-aspek pengalaman tertentu atau penilaian terhadap perbuatan tertentu. Value judgments ini nantinya terbuka menjadi factual judgments ketika keputusan pertama ini telah diungkap (explored). (Fraenkel, 1977: 25)

Oleh karenya siswa dilatih melakukan values judgements dari fakta dan data sains sehingga mereka akan terlatih dan memiliki kepedulian terhadap values dalam setiap mereka mempelajari sains yang selanjutnya menjadi bagian utama alasan mereka ketika melahirkan value judgments berdasarkan fakta dan data sains.

Kemampuan guru dalam melaksakan pendekatan seperti ini dibutuhkan meskipun saat ini kemampuan untuk seperti ini secara metodis belum merata dimiliki oleh guru sains untuk tidak mengatakan sesuatu yang langka bagi guru-guru sains. Di sini guru dituntut tidak saja menguasai dan memahami nilai-nilai yang hidup didalam agama, kehidupan sosial, dan alam jagad raya tetapi memahami lebih dalam tuntutan dari sebuah values misalnya perlu diperlukan kompetensi tersendiri. Karena bagaimanapun seorang guru perlu menyadari apa yang diingatkan oleh Guire dan Tuchanska, bahwa we must not only clarify the descriptive aspects of actual scientific community but their normative dimensions as wells. (Guire, 2000: 287)

Mata kuliah semisal Filsafat Moral, dan TImu Akblaq sebagai basis filosofis kemudian diikuti misalnya dengan Pendidikan Nilai, dan Pendidikan Moral atau Pendidikan Karakter dan seumpamanya, sebagai implementasi metodis pembelajarann yang mesti menjadi kompetensi tersendiri bagi guru-guru sains. Tanpa memiliki kompetensi seperti ini kesukaran implementasi pembelajaran sains yang mengikutkan values sebagaimana banyak dituntut oleh para ahli saat ini, akan menjadi sia-sia, akhirnya pembelajaran sains akan kembali dalam struktur pembelajaran sains yang telah berlangsung selama ini yang telah mendapat banyak kritik oleh para ahli.

3. Hadharat an-Nas, al-Ilm al-Falasafah Sebagai Basis Nilainisasi Pembelajaran Sains Integratif-Interkonektif

Seperti telah diungkap sebelumnya bahwa misi integrasi-interkoneksi antara ilmu dan agama bahwa tidak hanya sebatas memutus dikhotomis Islam dan ilmu tetapi juga dimuati oleh missi bagi penumbuhkembangan nilai-nilai agama, kemanusiaan dan sosial dalam mengkaji dan mengembangkan ilmu umum dalam hal ini sains, sehingga sains baik secara struktural-metodologis maupun secara moral-ontologis sains dan values menjadi bagian satu dengan yang lainnya.

Tanpa bermaksud mengeyampingkan pemikiran integrasi yang telah sangat berkembang saat ini, namun pemikiran M. Amin Abdullah untuk kepentinga tulisan ini layak dipertimbangkan dalam membangun struktur pembelajaran sains yang berbalut nilainisasi.Sungguhpun diakui bahwa beliau belum menampilkan secara eksplisit model pembelajaran sains integrasi-interkoneksi, namun konsepnya pada pengkajian dan pengembangan ilmu-ilmu keislaman setidaknya dapat dijadikan pilihan untuk dikembangkan bagi pembelajaran sains integrasi-interkoneksi yang berorientasi pada nilainisasi. 
Pemikiran M. Amin Abdullah dalam pengembangan ilmu-ilmu keislaman dalam format integrasi-interkoneksi ini yang dapat diadopsi setidaknya pada konsep apa yang disebutnya dengan hadharat an-nas, al-ílm dan al-falasafah. Ketiga konsep ini diperkerjakan secara bersinergis dan menyatu.

Dimaksudkan dengan hadharat an-nash (budaya teks) adalah upaya yang kuat untuk menggali, memahami dan menimbang kandungan isi teks keagamaan sebagai wujud komitmen keagamaan dan keislaman. Buah kebenaran ilmu yang diperoleh cenderung intelektualis-teologis, mengabaikan intelektualis-sosiologis. Hadharat al-ílm, adalah (budaya ilmu pengetahuan) ditandai dengan upaya yang kuat untuk menggali bidang keilmuan yang digeluti demi profesionalitas, objektifitas dan inovasitas sebagai tuntutan ilmiah ilmu pengetahuan. Orientasi kerja cenderung pada ranah sosial-humaniora sains dan teknologi yang dibangun di atas fakta-fakta fenomena sosial maupun kealaman yang cenderung mengabaikan keberpihakan pada kehidupan manusia dan lingkungan hidup. Terakhir hadharatal-falasafah (budaya filosofis-etis) adalah ditandai dengan upaya yang kuat menimbang dan menggaiktkan muatan ilmu pengetahuan dengan tanggungjwab moral etis transformatif-emansipatoris. Aksentuasi orientasi kerjanya pada tanggung jawab moral etis dalam praksis kehidupan riil masyarakat.(Amril M, 2016:15-18)

Ketiga piranti nilainisasi pembelajaran sains ini mutlak disinergikan, karena jika tidak dilakukan sains dan values tidak akan pernah terintegrasi-terinterkoneksi. Dengan membangun struktur nilainisasi pembe;alajaran sains integratif- interkonektif seperti ini sains yang dipelajari akan selalu tersentuh dengan values yang berbasis pesan-pesan moral teks sekaligus berorientasi pada kemaslahatan moral etis kehidupan umat manusia dan alam jagad raya secara ilmiah dengan temuan sains dan teknologi yang terus berkembang. Sedemikian rupa siswa dalam pembelajaran sains tidak lagi terpaku pada fakta dan data yang diobjektivikasikan dan dirasionalisasikan menurut kepentingan metodis sains itu sendiri.

\section{SIMPULAN}

Pembelajaran sains yang tidak mengikutkan values ternyata secara epistemologiseksistensial sudah tidak dapat dipertahankan lagi. Kenyataan seperti ini tidak saja lantaran sains itu sesungguhnya merupakan hasil olah akal budi manusia yang tidak dapat dipisahkan dari values, juga keberadaan sains itu sendiri sesungguhnya hidup dan berkembang di dalam masyarakat yang tidak berada dalam ruang hampa values.

Ketiadaketerpisahan sains dan values dalam tatapan ontologis dan eksistensial seperti diungkap di atas tentu menjadikan sesuatu yang syah-syah saja ketika mencuatkan kritikan tajam oleh para ahli, khususnya pemikir pendidikan terhadap kinerja pembelajaran sains yang selama ini dinilai meninggalkan bahkan menafikan values. Seiring dengan itu kebermunculan pemikiran-pemikiran solusif yang produktif bagi pembelajaran sains yang mendasari dan mengikut sertakan values sampai saat ini terus berlangsung dan memang sangat diharapkan.

Melalui struktur pembelajaran sains dengan paradigma keilmuan integrasiinterkoneksi ini yang ditopang oleh dua alasan di atas menunjukkan bahwa keterkaitan sains dan values merupakan suatu keniscayaan.

Paradigma keilmuan integrasi-interkoneksi yang saat ini telah menjadi paradigma keilmuan di lembaga pendidikan Islam, khususnya di PTKI dapat ditempatkan sebagai salah satu alternatif pilihan yang solusif bagi pembelajaran sains yang mengikut sertakan values. Pilihan pada integrasi-interkoneksi ini diantaranya, bukankah mengikutsertakan values 
dalam setiap ilmu pengetahuan, yang selama ini diabaikan, menjadi salah satu missi dari paradigma ilmu integrasi-interkoneksi.

Berbasiskan pada hadharat an-nash (budaya teks), hadharat al-ilm (budaya ilmu pengetahuan) dan hadharatal-falasafah (budaya filosofis-etis) kemudian diikuti dengan mengimplementasikan pendekatan filosofis-analitik saintifik dan penedekatan eksplanatif dan ekploratif nilai keagamaan dan sosial dalam praktis pembelajaran, dapat dikatakan merupakan sebuah struktur pembelajaran sains yang tidak lagi meninggalkan values. Sedemikian rupa turunan negatif yang dihasilkan oleh pembelajaran sains yang meninggalkan values niscaya dapat dieliminasi, sebaliknya tentu akan lahir sains yang berpihak pada keilahiyahan, kemanusiaan dan ekologial, selanjutnya akan terbuka produk sains yang rahmatan li al-'alamin.

$\mathrm{Di}$ atas ini semua tentunya sangat ditunggu disain pembelajaran integratifinterkonektif bagi pembelajaran sains yang menempatkan atau menjalinkelindan-kan fakta dan data sains dengan values sains yang terimplementatif baik di tingkat Sekolah Dasar, Menengah Pertama (SMP/Tsanawiyah), Menengah Atas (SMA, MA, Kejuruan) bahkan di tingkat Perguruan Tinggi Keagamaan Islam/Umum. Semoga!!!

Berdasarkan hasil pengolahan dan analisis data penelitian yang telah diuraikan sebelumnya, maka dapat disimpulkan bahwa siswa yang masuk kategori penilaian kesadaran metakognisi: Belum Berkembang (BB) dan Masih Sangat Beresiko (MSB) (0\%). Artinya, tidak ada lagi siswa yang belum menggunakan metakognisi; Belum Begitu Berkembang (BBB) $(1,26 \%)$. Artinya, siswa belum mampu memisahkan apa yang dia pikirkan; Mulai Berkembang (MB) (16,91\%). Artinya, siswa telah dapat dibantu untuk sadar akan cara berpikirnya; Sudah Berkembang Baik (SBB atau OK) (68,23\%). Artinya, siswa telah sadar dengan cara berpikirnya; dan Berkembang Sangat Baik (BSB atau super) (13,60\%). Artinya, siswa telah menggunakan kesadaran metakognisi secara teratur. Strategi metakognisi yang digunakan oleh siswa dalam belajar ialah membuat ringkasan, menggarisbawahi bahan bacaan, dan membuat pertanyaan serta menjawabnya sendiri $(26,41 \%)$; membuat ringkasan dan menggarisbawahi bahan bacaan (18,09\%); membuat ringkasan, menggarisbawahi bahan bacaan, membuat peta konsep, dan membuat pertanyaan serta menjawabnya sendiri $(10,76 \%)$, dan hanya membuat ringkasan $(10,76 \%)$.

\section{REFERENSI}

Amril M, Epistemologi Integratif-Interkonektif Agama dan Sains (Menggali Potensi-Konsepsi Menuju Teori-Aplikasi dalam Pengembangan Ilmu Keislaman dan Pembelajaran), Rajawali Press, Jakarta, 2016

-, Integrasi Sains dan Values dalam Pendidikan (Sebuah Upaya Metodologis Pebelajaran, Lembaga Penelitian dan Pengembangan Masyarakat UIN Suska Riau, 2013.

"Integrasi Sains dan Values Dalam Pendidikan (Sebuah Upaya Metodologis Pembelajaran", Makalah dipresentasikan pada AICIS ke XII, Surabaya 2012

, "Nilainisasi Ilmu (Sebuah Upaya Integrasi Ilmu dalam Pembelajaran Sekolah di Era Globalisasi)" dalam Al-Fikra, Jurnal Ilmiah Keislaman,Vol. 7. No. 2.JuliDesember. 2008.

-----------, Metodologis-Epistemologis di Perguruan Tinggi Islam (Telaah Pemikiran Al-Faruqi, alAttas dan Sardar Bagi Pengembangan IAIN ke UIN), Pusat Penelitian IAIN Sulthan Thaha Syaifuddin Jambi, 2002.

Capleston, Frederick, A History of Philosophy, Vol. V, Search Press, London, 1975

Fraekel, R, Jack, How to Teach About V alues: An Analytic Approach, Englewood Cliffs, New Jersey, 1977. 
Guire, Mc, J.E \& Barbara Tuchanska, Science Unfetterd, Ohio University Press, Ohio,2000.

Henk Verhook, "Science Education in Universities" dalam Bert Musschenga and David Gosling (Ed), Science Education and Ethical V alues Introducing Ethics and Religion into The Classroom and Laboratory, Georgetown University Press, Wasington DC, 1985.

Muhmidayeli, Filsafat Pendidikan, cetakan ke 2, Refika Aditama, Bandung, 2012 , "Kebebasan dan Tangungjawab Moral: analisis Filosofis Pencarian Pembenaran Nilai Moral dalam Kaitannya dengan Normativitas Agama: dalam Al-Fikra, Jurnal Ilmiah Keislaman, Vol.7. No.2. Juli-Desember 2008.

----------, "Sekolah dan Transformasi Masyarakat: Keniscayaan Nilai-Nilai Moral) Pengantar Buku dalam Amril M, Etika dan Pendidikan, Aditya Media, Yogyakarta, 2005

R. Harre, The Philosophies of Science, an Introductory Surveys, The Oxford University Press, London, 1995. 